\title{
OBITUARY \\ Dr. SOSSENHEIMER
}

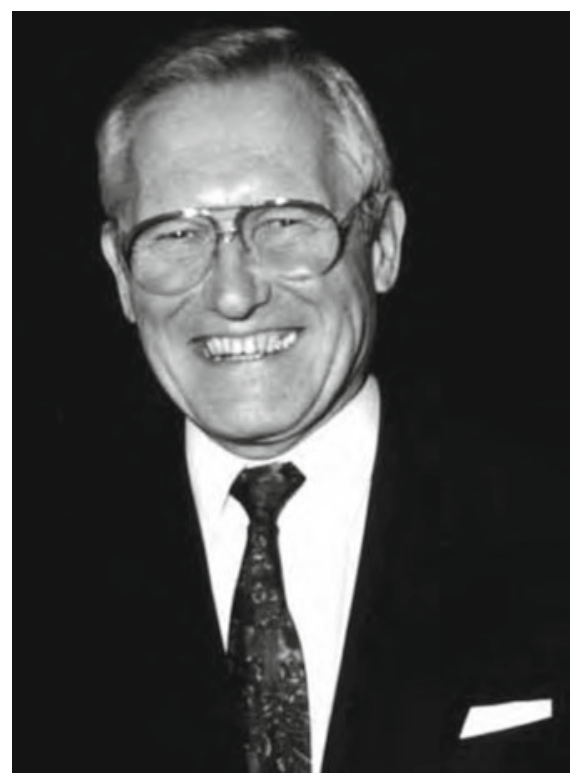

Dr.-Ing. Dr.-Ing. E. h. Heinz Sossenheimer, former Executive Member of Board of DVS - German Welding Society died on the $8^{\text {th }}$ of July 2006 at the age of 81 years.

He graduated as an engineer at the University of Darmstadt in the field of welding technology and statics and dealt in his doctoral thesis with problems of structural steelwork. First an editor for the technical-scientific journal "Schweißen \& Schneiden" (Welding \& Cutting) of DVS from 1956 to 1958, Dr. Sossenheimer since then was assigned DVS Executive Member of Board for more than three decades. During this time DVS developed to a nationally and internationally well known society with high reputation. In 1959, Dr. Sossenheimer founded the DVS publishing house and became its director as well as of the "Forschungsvereinigung Schweißen und Schneiden", the German research association on welding and cutting of DVS, established in 1965.

Because of his merits both as a scientist and as a manager, in 1987 he was honoured with the title "Dr.-Ing. E. h." (honorary doctor) by the mechanical engineering institute of Dortmund University. As director of DVS publishing house he launched the journal "der Praktiker" for practical welders and other welding personnel as well as the English translation of the scientific articles of "Schweißen \& Schneiden" as a supplement of this journal.

Internationally $\mathrm{Dr}$. Sossenheimer was very successful in promoting the global cooperation of welding institutions. $\mathrm{He}$ was treasurer of the International Institute of Welding (IIW) and chairman of the "Publications" working group. "In recognition of his contributions to, and standing in, the welding engineering community at an international level", as the text of the honorary fellowship of The Welding Institute mentioned it, he was honorary member of several welding societies all over the world. His various activities won him also the honorary membership of many other institutions in Germany and abroad.

Dr. Sossenheimer served in many scientific and technical committees for international societies and conferences and he also provided specialist advice to many international projects. For example, he was chairman of the organisation committee for the Essen Welding Fair, the biggest trade show and trade fair worldwide in the field of welding and allied processes. Further on he was founding member of the European Welding Federation (EWF). In 1991, he was honoured with the highest award of the German Welding Society, the "DVS- Plakette" for his merits and excellent contributions in the field of welding and for the development of the German Welding Society. In 2003, DVS established a price with his name in the International Institute of Welding, the "Dr. Sossenheimer Software Innovation Award". 